\title{
Influence of Increasing Cement Content on some Geotechnical Properties of selected Lateritic Soils of Western Niger Delta on Sapele-Agbor Road, Nigeria
}

\author{
UGBE, FC; NWAKAJI, KN; *EMIOGE, EA
}

\author{
Department of Geology, Delta State University, PMB 1, Abraka, Nigeria \\ *Corresponding Author Email: emiogeemmanuel@gmail.com; Tel: +2347069339567
}

\begin{abstract}
This study is aimed at determining the influence of stabilization by percentage increase in volume of cement on Geotechnical properties of some lateritic soils obtained from two borrow pits along Agbor-Sapele road, Western Niger Delta, Nigeria. The soils are classified as A-7-6 and A-7-5 with high percentage of Fines, averaging $60.43 \%$. These natural soil samples falls short of the Federal Ministry of Works Standard based on grain size and consistency limits. The values of $1950.91 \mathrm{Kg} / \mathrm{m}^{3}$ and $22.70 \%$ obtained for maximum dry density (MDD) and optimum moisture content (OMC) when soil was treated at $10 \%$ by volume of cement, reveals the fact that higher unconfined compressive strength (UCS) values would be noticeable at $10 \%$ by volume addition of cement with increasing energy level of compaction, than that to be obtained at $5 \%$ by volume of addition of cement with MDD of $1933.80 \mathrm{Kg} / \mathrm{m}^{3}$ and OMC $22.78 \%$. When the soaked California Bearing Ratio (CBR) values for treated soils were considered, the reduction in soaked CBR value is minimal at $10 \%$, with an average of $76.33 \%$ than that obtained at $5 \%$ by volume of cement with an average of $78.45 \%$, compacted at varying energy level. In general, the study result clearly reveals that increasing cement content would result in improved strength characteristics even as permeability decreased from $6.744 \times 10^{-8} \mathrm{~mm} / \mathrm{s}$ to $6.129 \times 10^{-8} \mathrm{~mm} / \mathrm{s}$ across the compaction level of the stabilized soil samples.
\end{abstract}

DOI: https://dx.doi.org/10.4314/jasem.v25i11.6

Copyright: Copyright $(\odot) 2021$ Ugbe et al. This is an open access article distributed under the Creative Commons Attribution License (CCL), which permits unrestricted use, distribution, and reproduction in any medium, provided the original work is properly cited.

Dates: Received: 22 August 2021; Revised: 17 September 2021; Accepted: 06 October 2021

Keywords: Geotechnical Properties, Lateritic soils, Cement, Stabilization, California Bearing Ratio, Permeability

Lateritic soils are the product of intensive weathering that occurs under tropical and subtropical climatic condition resulting in the accumulation of hydrated Iron and Aluminium oxides (Gidigasu, 1972). These soils are found in dry flat lands and plains in both eastern and western Niger Delta and the soils in the region have been the major construction material for road construction. Several researches (Akpokodje, 1986; Omotosho and Eze-Uzomaka, 2008; Ugbe, 2011) have carried out geotechnical evaluation of properties as of lateritic soils. It should however be noted that limited works have being done in the western Niger Delta with regard to evaluating the geotechnical properties of these soils for use in pavement construction. The Niger Delta region is characterized by soils which are susceptible to decline in geotechnical properties, a situation closely related to its annual high precipitation which generally impacts negatively on the geotechnical properties of lateritic soil found in the flat plains. However, in addition to the volume of rainfall other factors that affect the formation and geotechnical properties of soil includes parent rock, climate, vegetation, topography/drainage condition and position in the soil profile. All these factors had been shown by various researchers to influence mineralogical, geochemical and hence geotechnical properties of the soils, (Ogunsanwo, 1988). In the work of (Tom and
Krishna, 2006), they opined that the desirable properties of lateritic soil used as sub grade materials includes; stability, incompressibility, permanency of strength, minimum changes in volume under adverse weather and groundwater conditions, good drainage and ease of compaction, which is of great concern to transportation and geotechnical engineers.

Hence, where these conditions are not met, soil stabilization processes are employed before such soils are considered suitable for use as road construction material, as observed by (Akpokodje, 1986b), who recommended the use of $3-5 \%$ by weight of cement to stabilize some lateritic soils of Eastern Niger Delta for use as road construction material. However this has not significantly improved the lateritic soils of Western Niger Delta. This may be largely attributed to fact that soil stabilization using 3-5\% by weight corresponding to $5-7 \%$ by volume of cement were only estimated value recommended for use only on A-1 soils (Little and Nair, 2009).

Thus, this research work is aimed at assessing the influence of increasing cement content on some geotechnical properties of selected lateritic soils of western Niger Delta o Sapele-Agbor Road, Nigeria. 


\section{MATERIALS AND METHODS}

The soils used in the study was taken from two borrow pits at two different Local Government Areas of Delta State, with a common access road network from either ends Agbor-Sapele road as shown in figure 1. The first location is a lateritic soil quarry site at kilometre five ( 5 $\mathrm{km}$ ) from College junction Agbor, with Coordinates of the two bulk samples points A and B are (N06 ${ }^{0} 13$ '14.7', and E006 $\left.{ }^{0} 10^{\prime} 50.2^{\prime \prime}\right)$ and (N06 ${ }^{0} 13^{\prime} 14.9^{\prime}$ ' and E006 ${ }^{0} 10^{\prime} 50.3^{\prime \prime}$ ') respectively, while the elevation of the sampled area is $102.7 \mathrm{~m}$ above the sea level. The second location is about two kilometers $(2 \mathrm{~km})$ from Amai junction, Obiaruku. The coordinate of the two bulk samples points $\mathrm{C}$ and $\mathrm{D}$ collected at the site are $\left(\mathrm{N}^{\circ} 5^{\circ}\right.$ 48'38' and E 006 09'54', ) and (N05 48'38.4'" and E006 $\left.{ }^{0} 09^{\prime} 54.3^{\prime \prime}\right)$. The average elevation of the sampled area is $127 \mathrm{ft}$ or $38.7 \mathrm{~m}$ above mean sea level. The ordinary Portland cement used in this test was obtained from cement store, at condition suitable for the test.

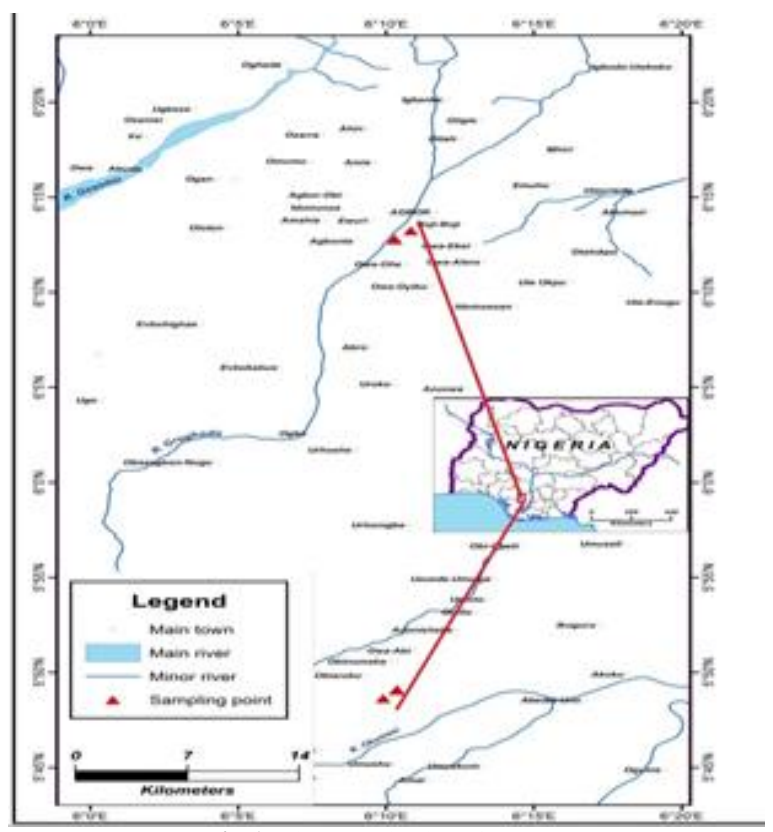

Fig 1. The samples location map

Sample Preparation: The soils moisture content was determined by the oven drying method, specific gravity of the soils, particle size distribution, plasticity characteristics where determined. The hydrometer method was used to obtain values for clay size $(\%<$ $0.002 \mathrm{~mm}$ ) fraction of the soil particle. The cement stabilized soils were prepared by treating the soils at $5 \%$ and $10 \%$ by volume of cement, where Portland cement was mixed to dried soil samples. Thereafter, water was continually added to the mixture in order to reach its optimum moisture content and allow for some time for soil cement reactions. After a while the soil-cement mixture was compacted (Standard Proctor compaction) at 27, 44 and 55 blows which correspond to West
African, intermediate and AASHTO modified energy levels.

California Bearing Ratio Test: California Bearing Ratio (CBR) test was developed by the California Division of Highway as a method of classifying and evaluating soil sub-grade and base course materials for flexible pavements. CBR test, an empirical test, has been used to determine the material properties for pavement design. Empirically, the tests measure the strength of the material and are not a true representation of the resilient modulus. It is a penetration test wherein a standard piston, having an area of 3 in 2 (or $50 \mathrm{~mm}$ diameter), is used to penetrate the soil at a standard rate of 1.25 $\mathrm{mm} /$ minute. The pressure up to a penetration of $12.5 \mathrm{~mm}$ and it's ratio to the bearing value of a standard crushed rock is termed as the CBR. The CBR $\geq 30 \%$ is proposed for a lateritic soils used for sub-grade. The higher the CBR of a soil sample, the better the strength of the soil.

Permeability Test: Soils are permeable, therefore allows the passage of water through the inner space or void between the grains. Some soils have high permeability while some have low permeability, water is not an asset in engineering and geotechnical works therefore it is important to measure the coefficient of permeability or hydraulic conductivity of the soil both in laboratory and on site to determine the rage of seepage rate, drainage rate settlement and compressibility of soil layers.

There are two permeability tests namely;

(1) The falling head permeability test for coarse aggregates and sand.

(2) The constant head permeability test for finer and clay soil.

However, the principle behind each test is the Henry Darcy's law of flow which states that "the quantity of fluid discharged per unit time $(\mathrm{t})$ is directly proportional to the cross sectional area (A) of the medium and the hydraulic head $\left(\frac{\Delta h}{\Delta l}\right)$ difference from the two points".

$$
\mathrm{K}=\frac{2.3026 \times a \times l}{A} \times \frac{\log \left(H_{1}-H_{2}\right.}{t_{2}-t_{1}}
$$

Where $\mathrm{K}=$ Permeability Coefficient; $\mathrm{A}=$ Cross sectional area of the sample; $\mathrm{a}=$ Cross sectional area of the standpipe; $1=$ length of the standpipe $=100 \mathrm{~cm} ; \mathrm{H}_{1}=$ Initial height of the water standing on the standpipe at the start of the experiment; $\mathrm{H}_{2}=$ Final height of the water on the standpipe at the end of experiment; $t_{1}=$ Initial time at the beginning of the experiment; $t_{2}=$ Final time at the end of the experiment. 


\section{RESULTS AND DISCUSSIONS}

Grain Size Distribution: The grain size distribution characteristics from mechanical sieve analysis and hydrometer test of the twelve sub-samples labelled $\mathrm{KN}$ 01 to KN12 is shown in figure 2. The sampled soils can be classified as well graded; with moderate plasticity, with it geotechnical properties summarized in table 1 below.

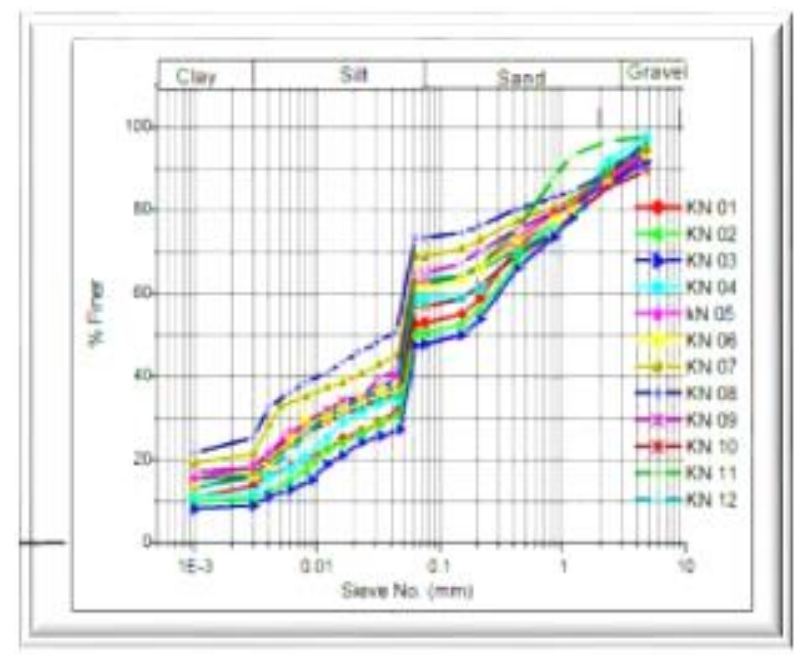

Fig 2. Soil samples grain size distribution plot

Table 1. The Summary of geotechnical properties of untreated soil

\begin{tabular}{ll}
\hline Properties & Value \\
\hline Average \% Fines & $60.43 \%$ \\
Liquid limit (LL) & 46.10 \\
Plastic limit (PL) & 26.54 \\
Plasticity Index & 19.55 \\
Soil type (AASHTO classification) & A-7 \\
\hline
\end{tabular}

According (Oyediran and Kalejaiye, 2011), soil aggregates with percentage of Fines less than 50\% tend to possess engineering characteristics that can be termed suitable than soils with percentage of fines greater than $50 \%$ are expected to pose field compaction problems when used either as sub-base or sub-grade. This position is consistent with the works of (Akpokodje, 1987 and FMWH, 1997), who recommended that the soil material to be used as sub-grade, sub-base and base course should consist of fines less than $35 \%$ by weight, passing BS sieve No. 200. Thus the soil under examination, with average $\%$ fines of $60.43 \%$ falls within this range considered to pose field compaction problems.

The Consistency Limit (Atterberg Limit): These limits and other related indices have proved to be very useful tools for soil identification and classification. It is often used directly in specifications for controlling soil for use in fill and in semi-empirical methods of design (Lambe and Whiteman, 1969). The summary of consistency limits reveals an average value of liquid limits (LL) as $46.10 \%, 26.54 \%$ and 19.55, for plasticity limits (PL) and plasticity index respectively (PI). This results falls within range of values reported by (Ramarmurthy and Sitharam, 2005). They reported the Atterberg limits of soils in the Niger-Delta to be generally moderate as (LL.39-86\%; PL 24-62\%) with values increasing with fines. Based on Casagrandes' chart, a plot of plasticity index against liquid limit was plotted and it indicates that the sampled soils are mainly CL and OL soils (Figure 3) below, equivalent of the A-7-6 and A-7-5 of AASHTO classification. This index classification is in conformity with (Ugbe, 2011).

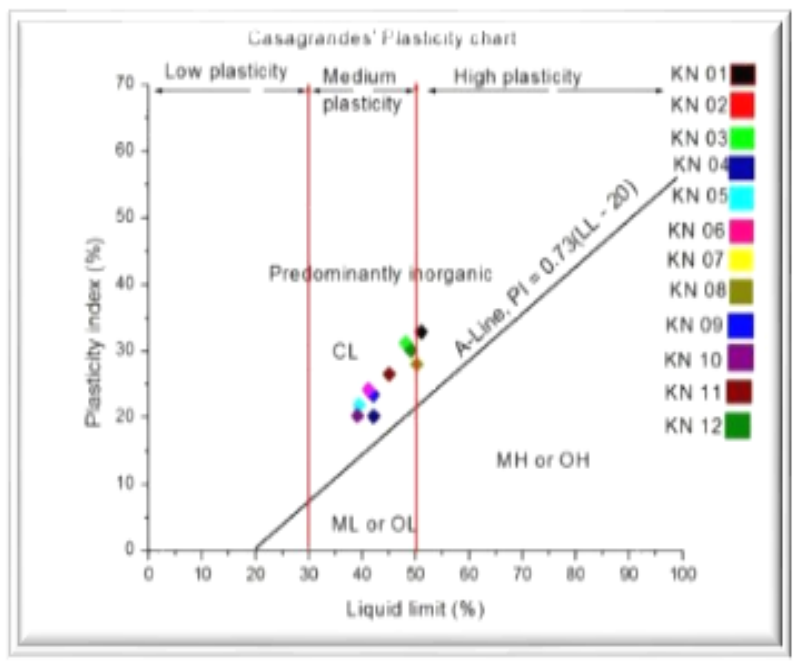

Fig 3.The soil samples classification based on Casagrande's plasticity chart

According to (Jegede, 2000) who recommend plasticity index not higher than $12 \%$, for base materials while the Federal Ministry of Works and Housing recommended not greater $20 \%$ plasticity index for soil used as subgrade material, $16 \%$ maximum for sub-base and $13 \%$ maximum for base course [FMWH, 1997).

When the lateritic soils are considered KN 1 - KN 6, KN $10-\mathrm{KN} 12$ fall within the range considered suitable for sub-grade. In general the lateritic soil examined can be considered to be only suitable as sub-grades as they fall short of the recommended standard. Federal Ministry of Works and Housing also recommended liquid limit of $40 \%$ maximum for sub-grade, $35 \%$ maximum for subbase and 30\% maximum for base course (FMWH, 1997).

When compared with this specification the value of liquid limit shown in table 4 . The sampled soils are largely considered as not suitable as base, sub-base and sub-grade material. KN 10 with liquid limit result of $39.17 \%$ may be considered an exception.

Mechanical Stabilization: The principle behind mechanical stabilization (soil compaction test) is that, 
the strength of soils increases with increase in dry density or dry unit weight, reduce compressibility and settlement of the road foundation. The result of mechanical stabilization of the soil samples compacted without cement at West African standard energy level indicates the maximum dry density (MDD) ranges from $1724.12 \mathrm{~kg} / \mathrm{m}^{3}$ - $1785 \mathrm{~kg} / \mathrm{m}^{3}$ and optimum moisture contents (OMC) ranges $17.82 \%-21.06 \%$ as shown in table 2 .

Table 2. The Maximum Dry Density and Optimum Water Content of

\begin{tabular}{lll}
\multicolumn{3}{c}{ untreated soil } \\
\hline Sample & MDD $\left(\mathrm{kg} / \mathrm{m}^{3)}\right)$ & OMC $(\%)$ \\
\hline A & 1785.28 & 17.82 \\
B & 1780.00 & 18.00 \\
C & 1724.12 & 21.06 \\
D & 1774.14 & 19.66 \\
\hline
\end{tabular}

According (O'Flaherty, 1988) the ranges of values that may be anticipated when using the standard Proctor test methods are: for clay soils, maximum dry density (MDD) may fall before $1.44 \mathrm{Mg} / \mathrm{m}^{3}$ and $1.685 \mathrm{Mg} / \mathrm{m}^{3}$ and optimum moisture content (OMC) may fall between $20-30 \%$.

For silty clay soils, MDD is usually between 1.6 and $1.845 \mathrm{Mg} / \mathrm{m}^{3}$ and OMC ranged between $15-25 \%$, while, for sandy clay soils MDD usually ranged between 1.76 and $2.165 \mathrm{Mg} / \mathrm{m}^{3}$ and $\mathrm{OMC}$ between 8 and $15 \%$ These soils from the study area could be classified as fine sand to silty clay.

The optimum moisture content (OMC) of compacted test for good backfilling material were given by (Akpokodje, 1986) to fall between $1.7-1.9 \mathrm{Mg} / \mathrm{m}^{3}$ and $7-15 \%$ respectively.

The "Nigerian General Standard Acceptable limits" stipulated by (FMWH, 1997), for any soils to be suitable for general filling and construction of sub-grade and subbase courses for roads should possess maximum dry density (MDD) above $1700 \mathrm{~kg} / \mathrm{m}^{3}$. The soils are thus judged suitable for use as general filling and as sub-grade materials.

Chemical Stabilization: The chemical stabilization was conducted using new and emerging approach; $\%$ by volume rather than $\%$ by weight of the stabilizer. This approach can be easily be replicated even by men with little formal education because no weighing is involved, it is easier and cheaper than stabilization using percentage by weight (Adeyemi et al, 2003).

Cement stabilization was carried out using preliminary estimate of $5 \%$ and $10 \%$ by volume of Portland cement, compacted at three energy level such as West African standard (27 blows), Intermediate energy (40 blows) and Modified AASHTO (55 blows).

From table 3 and 4 below, maximum dry density (MDD) values of cement stabilized soil samples using five $5 \%$ by volume ranges from $1730.50 \mathrm{~kg} / \mathrm{m}^{3}$ - $1933.80 \mathrm{~kg} / \mathrm{m}^{3}$ and optimum moisture content (OMC) values ranges from $17.60 \%-22.78 \%$, while, the (MDD) and OMC values of $10 \%$ cement stabilized samples ranges from $(1740.47-1950.91) \mathrm{kg} / \mathrm{m}^{3}$ and $16.92 \%-22.70 \%$ respectively.

The result indicates that, percentage increased in MDD with value ranging from $0.4 \%-3.3 \%$ and a minimum percentage decreased in $\mathrm{OMC}$ values ranging from $0.3 \%$ $-4 \%$ with increase in volume of cement.

Table 3. The increase in maximum dry density and decreasing optimum moisture content at $5 \%$ and $10 \%$ addition by volume of Portland cement under 27, 40 blows respectively

\begin{tabular}{|c|c|c|c|c|c|c|c|c|c|}
\hline \multirow[t]{2}{*}{ Sample } & \multirow{2}{*}{$\begin{array}{l}\% \text { by } \\
\text { Vol. of } \\
\text { PC }\end{array}$} & \multicolumn{4}{|c|}{ W/African } & \multicolumn{4}{|c|}{ Intermediate ( 40 blows) } \\
\hline & & $\begin{array}{l}\mathrm{MDD} \\
\left(\mathrm{kg}^{3} \mathrm{~m}^{3}\right)\end{array}$ & $\begin{array}{l}\% \\
\text { Iner. }\end{array}$ & $\begin{array}{l}\text { OMC } \\
(\%)\end{array}$ & $\begin{array}{l}\% \\
\text { Decr }\end{array}$ & $\begin{array}{l}\mathrm{MDD} \\
\left(\mathrm{kg} / \mathrm{m}^{3}\right)\end{array}$ & $\begin{array}{l}\% \\
\text { Inc. }\end{array}$ & $\begin{array}{l}\text { OMC } \\
(\%)\end{array}$ & $\begin{array}{l}\% \\
\text { Decr. }\end{array}$ \\
\hline $\bar{A}$ & 5 & 1804.93 & & 17.60 & & 1812.38 & & 18.49 & \\
\hline & 10 & 1870.43 & 3.5 & 16.92 & 4 & 1870.54 & 3.1 & 18.02 & 2.6 \\
\hline B & 5 & 1897.68 & & 18.44 & & 1908.03 & & 19.54 & \\
\hline C & $\begin{array}{l}10 \\
5\end{array}$ & $\begin{array}{l}1912.57 \\
1730.50\end{array}$ & 0.8 & $\begin{array}{l}18.34 \\
21.20\end{array}$ & 0.6 & $\begin{array}{l}1920.19 \\
1754.79\end{array}$ & 0.6 & $\begin{array}{l}19.09 \\
21.19\end{array}$ & 2.4 \\
\hline & 10 & 1740.47 & 0.6 & 21.13 & 3.3 & 1762.04 & 0.4 & 21.10 & 0.4 \\
\hline D & $\begin{array}{l}5 \\
10\end{array}$ & $\begin{array}{l}1780.1 \\
1813.57\end{array}$ & 1.8 & $\begin{array}{l}19.23 \\
19.15\end{array}$ & 0.4 & $\begin{array}{l}1813.00 \\
1836.00\end{array}$ & & $\begin{array}{l}20.60 \\
20.42\end{array}$ & 0.9 \\
\hline
\end{tabular}

Table 4. The increase in maximum dry density and decreasing Optimum Moisture Content at 5\% and $10 \%$ addition by volume of Portland cement at 55 blows.

\begin{tabular}{llllll}
\hline \multicolumn{5}{c}{ Modified AASHTO (55 Blows) } \\
\hline Sample & $\begin{array}{l}\% \text { by } \\
\text { vol of } \\
\text { PC }\end{array}$ & $\begin{array}{l}\text { MDD } \\
\left(\mathrm{kg}^{3} \mathrm{~m}^{3}\right)\end{array}$ & $\begin{array}{l}\% \\
\text { Increase }\end{array}$ & $\begin{array}{l}\text { OMC } \\
(\%)\end{array}$ & $\begin{array}{l}\% \\
\text { Decrease }\end{array}$ \\
\hline A & 5 & 1850.95 & & 18.86 & \\
& 10 & 1906.90 & 2.9 & 18.44 & 2.2 \\
B & 5 & 1933.80 & & 20.10 & \\
& 10 & 1950.91 & 0.9 & 20.00 & 0.5 \\
C & 5 & 1770.32 & & 20.78 & \\
& 10 & 1792.47 & 1.2 & 20.70 & 0.3 \\
D & 5 & 1832.46 & & 20.10 & \\
& 10 & 1850.00 & 0.9 & 20.00 & 0.5 \\
\hline
\end{tabular}

$P C=$ Portland cement.

California Bearing Ratio (CBR): CBR test for the cement stabilized soil was carried out using preliminary estimates of 5\% and 10\% by volume of Portland cement, compacted at these three different energy level West Africa, $(27$ blows) intermediate (40 blows) and Modified AASHTO (55 blows) was carried out. The unsoaked and soaked CBR were determined for $5 \%$ and $10 \%$ by volume of cement respectively, are summarized in the tables table 5 and 6 below. 
Table 5. The effects of soaking on CBR values at $5 \%$ by volume addition of Portland cement under 27, 40 and 55 blows.

\begin{tabular}{|c|c|c|c|}
\hline \multicolumn{4}{|c|}{ West African Energy Level (27 blows) } \\
\hline Sample & $\begin{array}{l}\text { Un-soaked } \\
\text { CBR (\%) }\end{array}$ & $\begin{array}{l}\text { Soaked } \\
\text { CBR (\%) }\end{array}$ & $\begin{array}{l}\% \text { Reduction } \\
\text { in CBR }\end{array}$ \\
\hline A & 35 & 8 & 77.1 \\
\hline B & 51 & 7 & 86.3 \\
\hline $\mathrm{C}$ & 26 & 10 & 61.5 \\
\hline $\mathrm{D}$ & 24 & 9 & 62.5 \\
\hline \multicolumn{4}{|c|}{ Intermediate (40 blows) } \\
\hline A & 52 & 8 & 84.6 \\
\hline $\mathrm{B}$ & 56 & 8 & 85.7 \\
\hline $\mathrm{C}$ & 50 & 10 & 80.0 \\
\hline D & 52 & 10 & 80.8 \\
\hline \multicolumn{4}{|c|}{ Modified AASHTO (55 blows) } \\
\hline A & 59 & 9 & 84.8 \\
\hline B & 51 & 9 & 82.4 \\
\hline $\mathrm{C}$ & 55 & 13 & 76.4 \\
\hline \multirow[t]{2}{*}{$\mathrm{D}$} & 58 & 12 & 79.3 \\
\hline & & Average & 78.5 \\
\hline
\end{tabular}

Table 6. The effects of soaking on CBR values at $10 \%$ by volume addition of Portland cement under 27, 40 and 55 blows.

\begin{tabular}{|c|c|c|c|}
\hline \multicolumn{4}{|c|}{ West African Energy Level (27 blows) } \\
\hline Sample & $\begin{array}{l}\text { Unsoaked } \\
\text { CBR }(\%)\end{array}$ & $\begin{array}{l}\text { Soaked } \\
\text { CBR }(\%)\end{array}$ & $\begin{array}{l}\text { \% Reduction } \\
\text { in CBR }\end{array}$ \\
\hline A & 40 & 6 & 85 \\
\hline B & 50 & 10 & 80 \\
\hline $\mathrm{C}$ & 25 & 10 & 60 \\
\hline $\mathrm{D}$ & 24 & 9 & 62.5 \\
\hline \multicolumn{4}{|c|}{ Intermediate (40 blows) } \\
\hline A & 47 & 9 & 80.9 \\
\hline B & 58 & 9 & 67.2 \\
\hline $\mathrm{C}$ & 56 & 11 & 80.4 \\
\hline D & 53 & 12 & 77.4 \\
\hline \multicolumn{4}{|c|}{ Modified AASHTO } \\
\hline A & 57 & 10 & 82.5 \\
\hline B & 59 & 10 & 83.1 \\
\hline $\mathrm{C}$ & 57 & 12 & 78.9 \\
\hline \multirow[t]{2}{*}{ D } & 59 & 13 & 78.0 \\
\hline & & Average & 76.3 \\
\hline
\end{tabular}

Permeability: Permeability being the ease or rate at which water is drain in soil is influenced by several factors ranging from soil structure, the grain size of the soil, the void ratio and arrangement of the pores, property of the pore fluid and degree of saturation (Gidigasu, 1974).Though, it is not a method of soil stabilization, drainage/permeability is a desirable property of any lateritic soil which could be used as road construction material (Tom and Krishna, 2006). Based on the grain size of the soil, permeability appears to be proportional to the square of effective grain size $\left(\mathrm{D}^{2}{ }_{10}\right)$ (Huangjing and Gasaluck, 2010), suggested $\mathrm{D}^{2}{ }_{50}$ for soils which do not have effective size. However, the relationship between the estimated permeability of the soil samples obtained from the effective grain size and the determined permeability from falling head permeability test is illustrated in Table 7, while (Figure 4 ), shows that a strong correlation between them, with $r$ $=0.8$

Table 7. The comparison between determined and estimated permeability of the soil samples

\begin{tabular}{llll}
\hline Sample & \multicolumn{3}{c}{ Permeability } \\
\cline { 2 - 4 } code & $\begin{array}{l}\mathrm{K}- \\
\text { Determined } \\
(\mathrm{mm} / \mathrm{s})\end{array}$ & $\begin{array}{l}\text { K - Estimated from } \\
\text { Mckinlays' }{ }^{2} \\
(1961)\end{array}$ & $\begin{array}{l}\text { \% difference } \\
\text { in k }\end{array}$ \\
\hline A & $6.508 \times 10^{-5}$ & $8.603 \times 10^{-5}$ & 32.2 \\
B & $6.405 \times 10^{-5}$ & $3.320 \times 10^{-5}$ & 48.2 \\
C & $6.134 \times 10^{-5}$ & $2.331 \times 10^{-5}$ & 59.4 \\
D & $6.227 \times 10^{-5}$ & $3.362 \times 10^{-5}$ & 46.0 \\
\hline
\end{tabular}

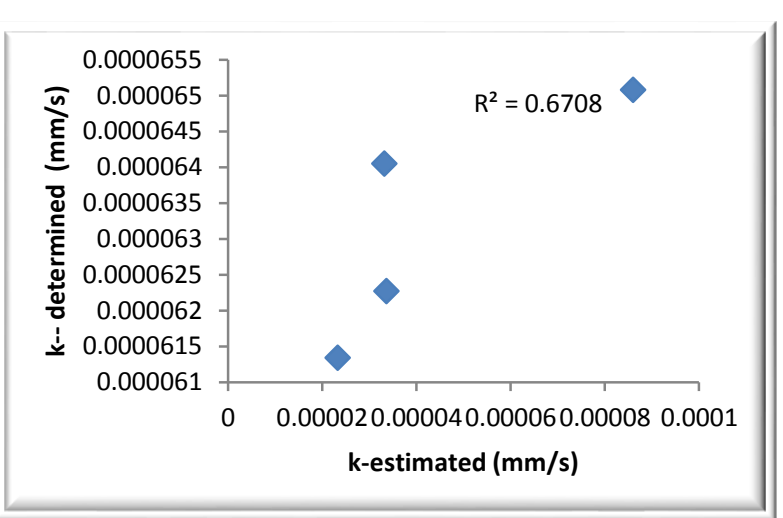

Fig 4. The graphical relationship between determined permeability and estimated permeability

The permeability values of the soil samples were compared with known standards $\left(10^{-5}-10^{-7} \mathrm{~cm} / \mathrm{s}\right)$ in [Gidigasu, 1974), which shows that the untreated soil samples corresponds to fine sand and silts dominated lateritic soil, which is in conformity with classification A-7/(CL) soils. These soils have poor drainage properties and low to very low degree of permeability (Kalita, 2011) as shown in the table 8.

Table 8. The table showing decrease of soil permeability and porosity with increasing number of blows at $5 \%$ and $10 \%$ by volume addition of Portland cement

\begin{tabular}{|c|c|c|c|c|c|c|c|}
\hline \multirow{2}{*}{$\begin{array}{l}\text { Sample } \\
\text { Code }\end{array}$} & \multirow[t]{2}{*}{$K$ and $n$} & \multicolumn{3}{|c|}{$5 \%$ by volume of Portland cement } & \multicolumn{3}{|c|}{$10 \%$ by volume of Portland cement } \\
\hline & & W/A & 40 blows & 55 blows & W/A & 40 blows & 55 blows \\
\hline \multirow[t]{2}{*}{$\mathrm{A}$} & $\mathrm{K}(\mathrm{m} / \mathrm{s})$ & $6.781 \times 10^{-8}$ & $6.566 \times 10^{-8}$ & $6.441 \times 10^{-8}$ & $6.351 \times 10^{-8}$ & $6.327 \times 10^{-8}$ & $6.301 \times 10^{-8}$ \\
\hline & Porosity & 0.31 & 0.28 & 0.26 & 0.23 & 0.23 & 0.22 \\
\hline \multirow[t]{2}{*}{ B } & $\mathrm{K}(\mathrm{m} / \mathrm{s})$ & $6.339 \times 10^{-8}$ & $6.332 \times 10^{-8}$ & $6.224 \times 10^{-8}$ & $6.340 \times 10^{-8}$ & $6.328 \times 10^{-8}$ & $6.249 \times 10^{-8}$ \\
\hline & Porosity & 0.24 & 0.22 & 0.22 & 0.23 & 0.23 & 0.22 \\
\hline \multirow[t]{2}{*}{$\mathrm{C}$} & $\mathrm{K}(\mathrm{m} / \mathrm{s})$ & $6.389 \times 10^{-8}$ & $6.286 \times 10^{-8}$ & $6.129 \times 10^{-8}$ & $6.226 \times 10^{-8}$ & $6.191 \times 10^{-8}$ & $6.099 \times 10^{-8}$ \\
\hline & Porosity & 0.33 & 0.32 & 0.29 & 0.30 & 0.29 & 0.28 \\
\hline \multirow[t]{2}{*}{$\mathrm{D}$} & $\mathrm{K}(\mathrm{m} / \mathrm{s})$ & $6.436 \times 10^{-8}$ & $6.392 \times 10^{-8}$ & $6.249 \times 10^{-8}$ & $6.277 \times 10^{-8}$ & $6.198 \times 10^{-8}$ & $6.177 \times 10^{-8}$ \\
\hline & Porosity & 0.29 & 0.28 & 0.27 & 0.28 & 0.27 & 0.26 \\
\hline
\end{tabular}


The results (figures 5 and 6) shows that the increase in the compaction energy level or number of blows and cements content of the soil samples resulted in a general decrease in permeability. This is indicative of a trend likely to continue upon increase in cement content at the various standard compact energy levels.

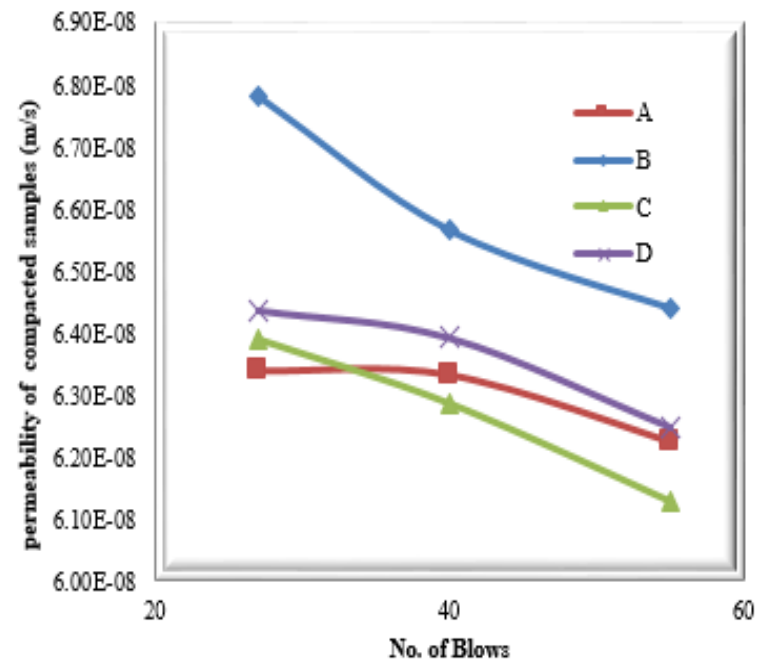

Figures 5. The graphical illustration of influence $5 \%$ by volume addition of cement of soil at 27,40 and 55 blows respectively

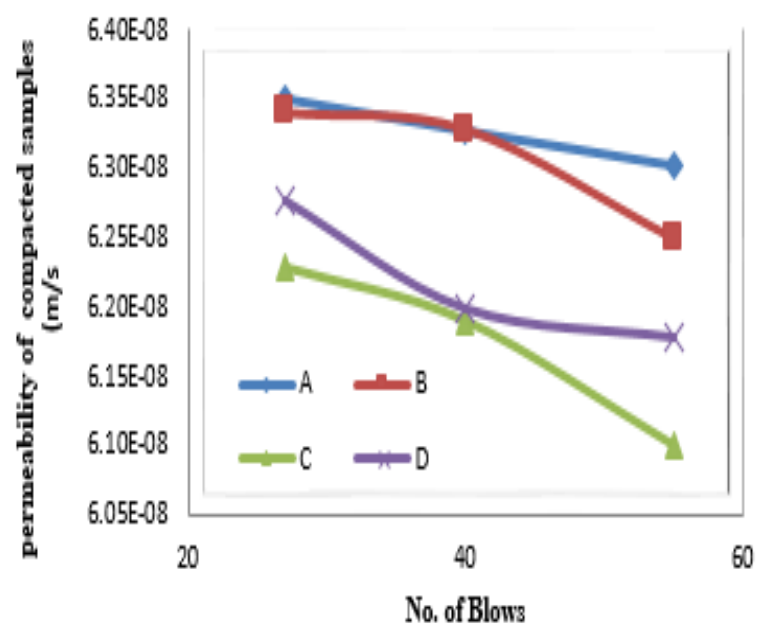

Fig 6. The graphical illustration of influence $10 \%$ by volume addition of cement of soil at 27, 40 and 55 blows respectively

Conclusion: The stabilization of the selected Lateritic soils by increasing cement content from $5 \%$ to $10 \%$ by volume of the soil-cement at varying energy of compaction have shown desirable improvement on it geotechnical properties in line with it suitability requirements.

\section{REFERENCES}

Adeyemi, GO; Owosanya, RA; Anokwu, FC (2003). Some Geotechnical properties of Cement Stabilized Granite - Gneiss derived Lateritic soil from Ile Ife South western Nigeria. J. Appl. Sci. Tec. 3(2): $8-12$.

Akpokodje, EG (1986a). The Geotechnical properties of Lateritic and Non-lateritic soils of South-Eastern Nigeria and other evaluation for road contribution. Bull. Int. Assoc. Eng. Geol. 33: 115-121.

Akpokodje, EG (1986b). A method of reducing the cement content of two stabilized Niger Delta Soils. Q. J. Eng. Geol. 19: 359-363.

Akpokodje, EG (1987). The Engineering Geological Characteristic and Classification of the major superficial soils of the Niger Delta. Eng. Geol. Environ. 32: 255-261.

Federal Ministry of Works and Housing (1997). Nigerian General Specifications (Roads and Bridges) Federal Ministry of Works and Housing, Lagos, Nigeria. 2(1):317.

Gidigasu, MD (1972). Mode of formation and Geotechnical characteristics of Lateritic materials in Ghana in Relation to soil forming factors, Engineering Geology. 4:79-91,

Gidigasu, MD (1974). Identification of Problem Lateritic Soils in Highway Engineering. A review Transportation Research Record. 9: 96 - 111.

Huangjing, S; Gasaluck W (2010). The Stabilization of Loess by Chemical Additives for Road Base. Elect. J. Geotec. Eng. 15:.1651-1668.

Jegede G (2000). Effects of Soil Properties on Soil Pavement Failure along F 209 Highway at AdoEkiti, Southwestern Nigeria. J. Constr. Build. Mater. 14:311-315.

Kalita, UC (2011). Soil Mechanics and Foundation Engineering, Prentice-Hall India Learning Private Limited, New Delhi. 98-176.

Lambe TW; Whitman RV (1969). Soil Mechanics. John Willey \& Sons, New York. 1:33-39.

Little DN; Nair, S (2009). Recommended Practice for Stabilization of Subgrade soils and Base", Research Program (NCHRP), A \& M University, Texas , Web only document-144:20-22.

Mckinlay, D G (1961). A Laboratory Study and Notes of Consolidation in charge with particular reference to condition of radial pore water drainage", Proceedings $5^{\text {th }}$ International Conference of Soil 
Influence of Increasing Cement Content on some Geotechnical Properties.....

Mechanics and Foundation Engineering. Paris, 1: 225-228.

O'Flaherty, CA (1988). Highway Engineering Edward Arnold Publishers, London, United Kingdom. 2(1):5

Ogunsanwo, O (1988). Basic Geotechnical Properties Chemistry and Mineralogy of some Lateritic Soils from South western Nigeria. Bull. Int. Assoc. Eng. Geol. Paris. 37:131 -135.

Omotosho, O; and Eze-Uzomaka, OJ (2008) Optimal Stabilization of Deltaic Laterite. J. Sci. Afri. Inst. Civ. Eng. 50(2): 10-17.

Oyediran, AI; Kalejaiye, M (2011). Effects of increasing cement content on Strength and Compaction parameters of some Lateritic soils in southwestern Nigeria. Elect. J. Geotec. Eng. 16: 1504.
Ramamurthy TN; Sitharam TG (2005). Geotechnical Engineering [soil mechanics], S; Chand \& Co., New Delhi. 29,190-245.

Terzaghi K; Peck, RB (1967). Soil Mechanics in Engineering Practice, John Wiley and Sons, New York. 2:729.

Tom, VM; Krishna Rao KV (2006). Introduction to Transportation Engineering, National Programme on Technology Enhanced Learning Web Course, 16.

Ugbe, FC (2011). Basic Engineering Geological Properties of Lateritic Soils from Western Niger Delta, Res. J. Environ. Earth Sci. 3(5): 571 - 577. 